Article

\title{
Consumer Purchase Intention toward Crowdfunding Products/Services: A Cost-Benefit Perspective
}

\author{
Yixiao $\mathrm{Li}^{1}$, Zhanda Zhang ${ }^{1}$, Ruiqin Wang ${ }^{2}$ and Yuangao Chen ${ }^{1, * \mathbb{C}}$ \\ 1 School of Information Management and Engineering, Zhejiang University of Finance and Economics, \\ Hangzhou 310018, Zhejiang, China \\ 2 School of Information Engineering, Huzhou University, Huzhou 313000, Zhejiang, China \\ * Correspondence: chenyg@zufe.edu.cn; Tel.: +86-571-87557125
}

Received: 5 June 2019; Accepted: 26 June 2019; Published: 28 June 2019

\begin{abstract}
With the popularity of crowdfunding, many small- and medium-sized ventures and startups which have insufficient funds advertise and sell their services or products in reward-based crowdfunding markets. The success of crowdfunding projects for sale purposes is therefore beneficial to the sustainable development of these growing enterprises. Based upon goal attainment theory, a research model based on a cost-benefit framework is proposed to analyze consumer purchase intention in reward-based crowdfunding markets. The research model is empirically tested with data collected from 398 participants in China. A structural equation modeling analysis reveal that perceived benefits (price concession and perceived innovation) exert a significant positive impact on perceived net goal attainment (PNGA), whereas perceived costs (transaction cost and performance risk) have a weak negative effect on PNGA. The results also indicate that satisfaction mediates between PNGA and purchase intention. Furthermore, we use an artificial neural network analysis to weigh the relative importance of the antecedents of PNGA. The results suggest that perceived innovation is more important than price concession, which is consistent with the structural equation modeling analysis. These results might deepen our understanding of how consumers trade off costs and benefits in the purchase of crowdfunding products/services.
\end{abstract}

Keywords: crowdfunding; cost-benefit framework; purchase intention; perceived net goal attainment; innovation

\section{Introduction}

Crowdfunding has become increasingly popular among the public, the business sector, and the public sector, as it provides an opportunity of collecting financial resources efficiently and conveniently $[1,2]$. Crowdfunding initiators call for the funding of specific projects and initiatives, while participants (also termed backers or sponsors) make contributions either by donating or in exchange for a reward. Such a fundraising approach is usually open to the "crowd" and implemented on the internet. Crowdfunding has been utilized for a number of different purposes, and several primary types are reward-based [3], equity-based [4], lending-based [5], and donation-based [6]. As a part of the internet economy, the development of online crowdfunding markets has been considered as a strategy in many countries, and the size of the world's crowdfunding markets is expected to approach $\$ 90$ billion by 2020 [1].

Small- or medium-sized enterprises and startups, as well as the self-employed and micro enterprises, are the building blocks of a large economy. Considering their size as well as other potential factors, they are likely to encounter difficulty in securing sufficient loans from banks, institutional investors, or governments $[7,8]$. The advent of crowdfunding, however, has created a simple yet effective channel of financing for economic entities of such levels. Once they have an idea 
about an innovative product or service but lack sufficient funds, they could turn to reward-based crowdfunding platforms that have been increasingly emerging on the internet [9]. For example, Kickstarter, a well-known platform, has been experiencing a rapid growth since its launch: Its statistics showed more than four billion dollars got pledged from a total of 15.8 million people, of which more than five million were repeated backers (accessed February 20, 2019). Similar to opening an Amazon/Taobao store, entrepreneurs can initiate a crowdfunding project with the click of a mouse on these platforms. They post the details of the project, including their funding targets and backers' choices and rewards, and they can use any features the platforms support, such as texts, pictures, videos, and live streaming, to decorate the project page. When a given amount of funds is accumulated within a certain period of time, the crowdfunding project is successful; otherwise, the funds are returned to the contributors. Considering the openness and low cost, such an online fundraising approach could play a prominent role in the sustainable development of many growing enterprises, thereby benefiting economic sustainability [1,9-11]. An emerging phenomenon in emerging crowdfunding markets is that crowdfunding has also been used as a marketing tool [12] — that is, many crowdfunding projects are devoted to advertising and selling products/services.

However, many innovative projects have failed in collecting enough funds, which poses a great challenge to both researchers and practitioners and casts a shadow over the crowdfunding industry $[13,14]$. According to its statistics, the success rate on Kickstarter was $36.68 \%$; that is to say, over half of the crowdfunding projects failed. To this end, understanding why crowdfunding projects succeed and why backers fund/invest has become critical to the future of crowdfunding. A number of studies have been devoted to understanding factors influencing backers' behavioral intentions based on different theories or from various perspectives [14,15], yet few studies have investigated backers' behavioral intentions from a cost-benefit perspective. Considering the coexistence of both negative and positive factors when purchasing products/services in a crowdfunding market that is less developed than professional e-commerce markets, such a perspective is therefore crucial and compelling.

The objective of this study is to apply goal attainment theory (GAT) contingent upon a cost-benefit framework in exploring consumer purchase intention toward crowdfunding products/services. GAT has a long history and has been widely used across various fields such as marketing, social psychology, and information systems (IS). The central tenet of GAT is that people's satisfaction is determined by perceived net goal attainment (PNGA), i.e., the extent to which their goals are attained $[16,17]$. A cost-benefit framework is usually contingent upon GAT, in which PNGA is jointly determined by both benefits and costs [17]. Anchored on GAT and research associated with crowdfunding and online shopping, we address the following questions: How do consumers' perceived benefits and costs of purchasing a crowdfunding product/service influence their PNGA? How does PNGA influence purchase intention? What is the relative importance of the benefits and costs to PNGA?

This study offers two major contributions to the existing literature on crowdfunding. First, despite a plethora of studies that have been devoted to studying behavioral intentions toward crowdfunding, previous research rarely examined how both benefits and costs arising from funding a crowdfunding project result in a trade-off effect over backers' funding intention. Grounded in GAT, we investigate how backers' PNGA from crowdfunding behavior is jointly determined by both benefits and costs, which would contribute to our understanding of backers' funding intention from a holistic perspective. Second, we identify several important benefits and costs that derive from purchasing a crowdfunding product/service and weigh their relative importance in shaping purchase intention. Specifically, two benefit factors, i.e., perceived innovation and price concession, and two cost factors, i.e., transaction cost and performance risk, are considered within the cost-benefit umbrella. Based upon SEM analysis, we further utilize artificial neural network analysis to have a robust understanding of their relative importance.

The remainder of this article is organized as the following. In Section 2, a review of the literature and theoretical foundation related to this study, including research progresses in the crowdfunding field and GAT, are presented. In Section 3, we discuss the research model and hypotheses therein. 
The next section is devoted to presenting the methodology of the research, including measurement development and data collection. The results based on both structural equation modeling and artificial neural network analyses are reported afterwards. In Section 6, we make a further discussion of the empirical findings. In the following section, the theoretical and practical implications and the limitations, as well as future research directions, are presented. Finally, a brief conclusion is offered.

\section{Literature Review and Theoretical Foundation}

\subsection{Literature Review on Crowdfunding}

A number of recent studies have been devoted to identifying factors affecting the success of crowdfunding projects from different perspectives. Kuppuswamy and Bayus [18] showed that the number of supporters is a critical factor in the success of a project. Kang et al. [19] revealed that backers of farther geographical distance and higher social capital are positively related to a higher funding performance. Moreover, backers' geographical distance plays the role of moderator in the relationship between their social capital and funding performance. Zhang and Chen [20] showed that the average number of reward options is related to the number of investors in an inverted-U shape. Considering the spreading of information in crowdfunding, the role of social networks has aroused many interests. By analyzing data from Facebook, Mollick [2] found that the better the social connection of a project, the higher the success rate. The effect of expression and description is also critical in crowdfunding. Parhankangas and Renko [21] identified that language style plays a crucial role in crowdfunding. Based on computer-mediated communication theory, Wang et al. [22] found that reply speed, reply length, comment score, and comment quantity have a positive effect on success rates by using a binary logistic regression model. Interestingly, comment affection positively moderates the effect of comment quantity on crowdfunding success. Their findings also indicated that more interaction information between fundraisers and backers leads to a higher success rate. By analyzing data from Startnext (German's largest crowdfunding platform), Crosetto and Regner [13] found that most successful projects achieve their funding targets during the final $25 \%$ of the funding duration, in which enhanced communication efforts exert an effect.

Understanding backers' behavioral intentions toward crowdfunding has also invoked a number of interesting studies. While fundraisers could call for investment among their relatives and friends at the initial stage of a crowdfunding project, its success is largely supported by unacquainted online investors [2]. Therefore, it is essential to understand what factors drive anonymous backers' behavioral intentions. It has been generally acknowledged that backers' trust has a remarkable positive impact on funding intention $[14,15,23,24]$. The findings from a survey conducted on experienced backers in Taiwan suggested that commitment and perceived risk might stimulate funding intention [15]. They explained that people usually think that higher risk possibly leads to greater returns in reward-based crowdfunding. Liang, $\mathrm{Wu}$, and Huang [14] found that the type of a project moderates the impact of backers' cognition and personality on their trust, while funding levels moderate the impact of trust on purchase willingness. Ho et al. [25] proposed a conceptual model to explore relationships between consumers' crowdfunding behaviors, perceived value, and purchase intention. They tested the model using data of 153 Taiwanese participants who purchased products on crowdfunding platforms. Their findings demonstrated that consumers' crowdfunding behaviors directly impact purchase intention and also exert an indirect influence through the mediation of perceived value. Interestingly, it is documented that herd behavior can arise in crowdfunding markets [26,27]. When investors are making investment/funding decisions, they are likely to follow with others because they believe that others know more than they do [27]. Bretschneider and Leimeister [26] evidenced that herding moderates the relationship between backers' reward motivation and investment. Davis et al. [28] suggested that there is a positive relationship between perceived product creativity and crowdfunding performance through the positive emotional reactions of consumers. Xiao and Yue [3] found that inertia behavior existed in repeated investment behavior, which indicated that backer's past reward option choice is 
related to the present reward option choice. Du et al. [29] found an inverted U-shaped relationship between reward options and backers' funding decisions.

\subsection{Goal Attainment Theory}

GAT was proposed by King [30] in the domain of nursing and was originally devoted to explaining how patients achieve their life goals in a dynamic context with various interaction relationships. It assumes that a number of factors could affect the attainment of patients' goals, which thereby determine satisfaction. Researchers have extended this theory to the IS field [17,31,32]. Sun, Fang, and Lim [17] explored contributors' satisfaction in virtual communities based on GAT. The findings showed that contributors' satisfaction is determined by their PNGA, which is defined as the degree to which one perceives that his/her salient individual goals are attained. In studies of technology-supported meetings, it was found that PNGA is positively related to both satisfaction with meeting outcomes and satisfaction with meeting processes [31,32]. Research in the marketing field has also highlighted the importance of goal achievement in consumer satisfaction [33,34]. Heitmann, Lehmann, and Herrmann [34] identified five goals which can be categorized into either approach or avoidance goals in determining consumption satisfaction. These studies proved that satisfaction is attributed to the degree to which net goals are perceived to be attained, which lies at the heart of GAT.

A successful application of GAT is usually accompanied by a cost-benefit framework [17,31,32], in which both positive and negative factors are antecedents to PNGA. Within such a framework, positive factors which are antecedents to PNGA are considered benefits, whereas negative ones are considered costs. Sun, Fang, and Lim [17] showed that the benefits of knowledge sharing include both extrinsic and intrinsic benefits, and costs include both actual and opportunity costs. When GAT meets a cost-benefit framework, PNGA is a trade-off between benefits and costs-that is, how much benefits of the goal attainment effort outweigh its costs. As such, a high level of the perceived benefits of fulfilling goals is not necessarily related to a high level of satisfaction, and vice versa. To fully capture the effect of goal attainment effort on satisfaction, a holistic view incorporates the potential costs that are associated with such an effort.

\section{Hypotheses Development}

Drawing on GAT and the cost-benefit framework, we propose a research model to examine factors influencing purchase intention toward crowdfunding products/services in the context of reward-based crowdfunding. In this model, two types of perceived benefits (price concession and perceived innovation) positively influence PNGA, and two types of perceived costs (transaction cost and performance risk) exert a negative effect. PNGA, which is therefore a tradeoff between perceived benefits, directly influences satisfaction. Furthermore, we posit that satisfaction mediates the effect of PNGA on purchase intention. The research model is depicted in Figure 1. 


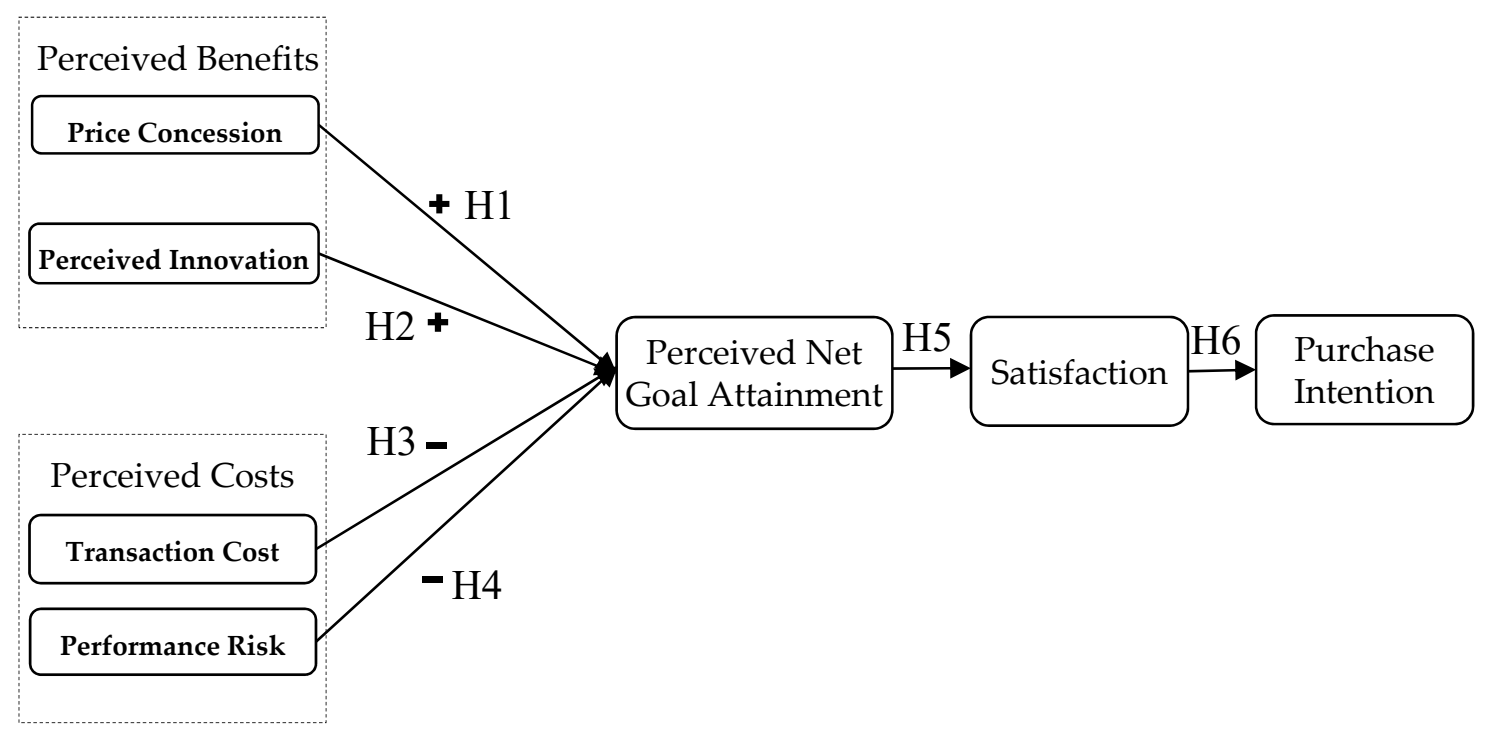

Figure 1. Research model.

\subsection{Perceived Benefits}

With regard to crowdfunding participants' perceived benefits, price concession should be the first to be investigated. Price has been always regarded as a crucial factor which affects consumer decision [35,36]. Despite the fact that online channels have changed the paradigm of business in many ways, it has been indicated that price is the most important factor in attracting and retaining customers to online stores [37]. Price strategies, such as discounting, are a common tool to lure online consumers into buying, and they increase sales correspondingly [38]. From a customer's perspective, a price concession brings economic benefits to him/her, thereby stimulating his/her positive emotions and increasing the willingness to buy [39-41]. Wei et al. [42] found that price concession has a positive impact on consumer purchase intention in fruit-related e-commerce. In line with their definition [42], we define price concession in the context of crowdfunding products/services as the extent to which buying crowdfunding products/services can save customers money compared with buying counterparts or substitutes in other channels, including offline channels such brick-and-mortar stores and non-crowdfunding online channels such as traditional e-commerce websites. An empirical study on a crowdfunding website revealed that a project's clear discount information is positively related to the total amount of funds finally collected [43]. Considering that consumers tend to maximize their PNGA and that most consumers are rational decision makers, the higher price concession associated with a crowdfunding product/service the higher customers' PNGA. Therefore, we hypothesize (H1):

\section{H1. Price Concession Has a Positive Impact on PNGA.}

Crowdfunding is inherently connected with innovation: Many innovative projects or creative ideas are supported by a group of anonymous individuals holding essentially the same belief-otherwise, they are underfunded $[13,15,44]$. Moreover, crowdfunding has the potential to foster an ecosystem of innovation. Backers contribute to the innovation process by providing necessary funds as well as valuable feedback/ideas [45]. Their recommendations and reviews on the internet could be highly beneficial to the adoption of new products/services among the public $[45,46]$. The innovation of a product/service can be either incremental or radical [47], and the previous literature has indicated that most products/services are incrementally innovative [15]. In line with the previous literature [15], perceived innovation refers to the degree to which a product/service is perceived to be innovative by consumers compared with other competing ones or substitutes. Innovation can arise respecting any property of a product/service, including those embedded in the manufacturing process [48] and the marketing process [49]. It has been documented that backers' perceived innovation is negatively related to their perceived risk, which, in turn, impacts their funding intention in crowdfunding [15]. 
When purchasing a crowdfunding product/service, a high level of consumers' perceived innovation could predict their utility from using the product/service. Hence, we propose $(\mathrm{H} 2)$ :

H2. Perceived Innovation Has a Positive Impact on PNGA.

\subsection{Perceived Costs}

Transaction cost refers to the costs involved in transaction-related activities of a purchase process [50,51], such as searching relevant information, communicating with the seller, and monitoring the ongoing process. Since most consumers are rational or semi-rational, they seek to minimize, or least reduce, transaction cost. Research indicated that consumers' perceived transaction cost negatively impacts their behavioral intentions in various online contexts [50-53]. Consumers might perceive more transaction cost when purchasing in crowdfunding markets than they do when purchasing in well-developed e-commerce markets. This could be attributed to several factors. First, information is rather asymmetric in crowdfunding markets. Most fundraisers are small- or medium-sized enterprises, startups, and even individuals. Consumers can find less information about them compared with large-sized or developed enterprises. In addition, considering the newness of many crowdfunding products/services, consumers might have difficulty finding other competing ones or substitutes. They have to spend much time searching for information and communicating with the sellers in order to ascertain the value of the products/services. Second, fundraisers usually spend a long period of time collecting funds, bringing about a high time cost of the transaction process to consumers. An empirical analysis of Startnext data showed that the mean funding duration of the projects was 53.96 days [13]. Compared with purchasing products/services on the mainstream e-commerce websites, purchasing crowdfunding products/services actually costs much more time. In addition, consumers have to monitor the funding process closely in case that the funding target has not yet been reached. Therefore, we hypothesize (H3):

\section{H3. Transaction Cost Has a Negative Impact on PNGA.}

Online shoppers face more risk than offline shoppers do [54,55]. Consumers' perceived risk is negatively related to their perceived value $[55,56]$ and thereby directly or indirectly influences purchase intention [57]. In the context of purchasing crowdfunding products/services, we define performance risk as the extent to which consumers perceive that crowdfunding products/services will not function as expected. There are several reasons that performance risk is a crucial factor in this context. First, as mentioned earlier, the funding duration of crowdfunding projects usually spans several weeks [13], so consumers have to wait a much longer time to get the products/services than they have in the context of normal e-shopping. Second, products/services in reward-based crowdfunding markets are usually provided by small- and medium-scale businesses or even individuals [12], of which the risk regarding many aspects, such as operation and production, is much higher than that associated with transacting with large-scale businesses. Third, innovative products/services are inherently associated with higher risk than non-innovative ones [56]. Actually, the low level of the success rate of crowdfunding projects indicates that many people have given up their belief in risky ones. In this cost-benefit framework, we consider performance risk as a type of cost owning to its negative effect on PNGA. Specifically, we have the following hypothesis (H4):

H4. Performance Risk Has a Negative Impact on PNGA.

\subsection{Satisfaction as a Mediator between PNGA and Purchase Intention}

Consumer satisfaction refers to a consumer's subjective evaluation of his/her consumption experience with a service/product [58]. While satisfaction is a buzzword permeating both practices and research in various fields such as marketing [58,59] and IS [17,60], evidence has also been presented that participant satisfaction plays an important role in crowdfunding [61,62]. By using asymmetric 
analytics, $\mathrm{Xu}$, Zheng, $\mathrm{Xu}$, and Wang [61] investigated the roles of project performance, including delivery timeliness, product quality, project novelty, sponsor participation, entrepreneur activeness, and sponsor demographics, in building sponsor satisfaction. Zheng, $\mathrm{Xu}$, Wang, and $\mathrm{Xu}$ [62] showed that sponsors' perceived utilitarian and hedonic values jointly determine their satisfaction in reward-based crowdfunding. An underlying assumption of GAT is that PNGA, i.e., the extent to which a user perceives that his/her goals are achieved, determines his/her satisfaction [17,31,32]. For example, in transactional virtual communities, contributors' satisfaction is determined by their PNGA [17]. In the same vein, the higher consumers' PNGA, the more satisfied they feel from purchasing crowdfunding products/services. Thus we hypothesize (H5):

H5. PNGA has a positive impact on satisfaction.

In this study, purchase intention refers to consumers' willingness to buy products/services in reward-based crowdfunding markets. Consumer satisfaction is a decisive predictor of purchase intention in both offline [58] and online [63] contexts. A considerable amount of research of consumers' repeated purchase intention, i.e., consumer loyalty, also indicated that satisfaction and loyalty are inextricably connected $[59,60,64-66]$. Likewise, in the context of purchasing crowdfunding products/services, the more satisfied consumers feel from purchasing and using them, the higher their intention of purchasing them in the future. Therefore, we further anticipate that satisfaction will exert a positive impact on purchase intention in this research model. As such, satisfaction is a mediator between PNGA and purchase intention, considering the hypothesized relationship between PNGA and satisfaction. Specifically, we have the following hypothesis (H6):

H6. Satisfaction Has a Positive Impact on Purchase Intention toward Crowdfunding Products/Services.

\section{Methodology}

\subsection{Measurement Development and Pilot Test}

In this study, most measurement items were developed based on existing scales validated in previous studies. Items measuring price concession were adapted from those in the study of online fruit purchasing [42]. We developed items of perceived innovation based on a previous scale, which was also operationalized in the context of crowdfunding [15]. Considering the scale of perceived product innovation with three items [67], the variables for measuring perceived innovation of crowdfunding products/services were operationalized with three items which were checked and validated by a pre-test procedure. To measure transaction cost, we borrowed the corresponding items in a study of online buying [50] and a study of the online bidder's repurchase intention [51]. Transaction costs regarding information search, communication, and process monitoring were considered, as suggested by the previous literature [50,51]. Measurement items for performance risk were adapted from Yang, $\mathrm{Yu}, \mathrm{Zo}$, and Choi [56] to reflect the potential risk that comes with crowdfunding products/services, respecting the gap between the actual performance and consumers' expectation. The variable of PNGA was operationalized with four items, adapted from Briggs, Reinig, and de Vreede [31] and Sun, Fang, and Lim [17], whose works were based on GAT as well as a cost-benefit framework. To measure satisfaction, we adapted and modified the scales used by Sun, Fang, and Lim [17], Spreng et al. [68], and Bhattacherjee [69]. Items of satisfaction were devoted to assessing a consumer's overall experience with a service/product. The dependent variable of purchase intention toward crowdfunding products/services in this study was operationalized with three items which were adapted from Dodds et al. [70] and Chu and Lu [71].

All items were measured using a seven-point Likert scale ranging from one (strongly disagree) to seven (strongly agree). To ensure that there were no significant differences between the English and Chinese scales, a back-to-back translation procedure was performed. Before pre-test and pilot test, a procedure of instrument validation was performed to ensure the validity of the instrument [72]. An expert panel consisting of three IS professors and three e-commerce practitioners took part 
in the procedure. The content validity and construct validity of the instrument were guaranteed. Further, a pre-test was conducted on 20 postgraduate students to check the content validity of the instrument. According to their feedback, the wording and format of the questionnaire were improved. Later, a pilot test was conducted on 70 undergraduate students to validate the instrument. Using SPSS (Version 20, IBM, USA), we computed the Cronbach's $\alpha$ values of the constructs to check the instrument's construct reliability. We discarded a small number of items that lowered the $\alpha$ value of the corresponding constructs in order to ensure that all $\alpha$ values were above the recommended level of 0.70. The measurement items are listed in the Appendix A.

\subsection{Data Collection and Demographic Analysis}

We randomly intercepted shoppers/visitors at three shopping centers in two populous cities (Hangzhou and Huzhou) in east mainland China. They were asked whether they had purchased crowdfunding products/services, and those who had such an experience were invited to participate in the survey. The questionnaire included an introduction of several famous reward-based crowdfunding platforms in mainland China such as Jingdong crowdfunding and Taobao crowdfunding. To encourage participation, they were paid 20 RMB. The collection process lasted for three days. Finally, 398 valid responses were collected after discarding 52 invalid answers, yielding a response rate of $88.4 \%$.

Demographic information includes gender, age, education, online shopping experience, and annual income. The sample consisted of 158 men (39.7\%) and 240 women $(60.3 \%)$ who came from 28 provinces or regions in China. As for online shopping experience, over 90 percent of people had an experience of more than three years. The age distribution shifted toward cohorts of $18-45$ years old. Most respondents had a college education background. The annual incomes of the sample were approximately normally distributed, which centered on 60-120 thousand. Other demographic statistics of the sample are reported in Table 1.

Table 1. Demographic analysis results.

\begin{tabular}{llcc}
\hline \multirow{2}{*}{ Classification } & \multicolumn{1}{c}{ Items } & Frequency & Percentage \\
\hline \multirow{2}{*}{ Gender } & Male & 158 & 39.7 \\
& Female & 240 & 60.3 \\
\hline \multirow{3}{*}{ Age } & Under 18 & 5 & 1.3 \\
& $18-30$ & 202 & 50.7 \\
& $31-45$ & 172 & 43.2 \\
& Over 46 & 19 & 4.8 \\
\hline \multirow{4}{*}{ Education } & Junior high school & 6 & 1.5 \\
& Senior High school & 23 & 5.8 \\
& Junior college & 62 & 15.6 \\
& College & 285 & 71.6 \\
& Over undergraduate & 22 & 5.5 \\
\hline \multirow{4}{*}{ Shopping experience online } & Under 3 years & 18 & 4.5 \\
& 3-6 years & 177 & 44.5 \\
& 6-10 years & 163 & 40.9 \\
& Over 10 years & 40 & 10.1 \\
\hline \multirow{3}{*}{ Annual income } & Under 30 thousand & 46 & 11.6 \\
& 30-60 thousand & 89 & 22.4 \\
& 60-120 thousand & 165 & 41.4 \\
& 120-200 thousand & 81 & 20.3 \\
& Over 200 thousand & 17 & 4.3 \\
\hline \multirow{3}{*}{} & & &
\end{tabular}




\section{Results}

\subsection{Structural Equation Modeling Analysis}

\subsubsection{Reliability and Validity}

We resorted to a covariance-based structural equation modeling (SEM) approach to validate this model. Following a standard SEM procedure, the SEM analysis included two stages. In the first stage, we examined the reliability and validity of the measurement model. In the second stage, the path coefficients and other estimates of the structural model were computed by using AMOS (a popular covariance-based SEM software).

To test the reliability and validity of the model, we first performed an exploratory factor analysis. The results are reported in Table 2, from which seven factors are exacted, and each measurement item is correctly classified. Notice that the coefficients between items and factors, which are less than 0.4 , are not displayed. Hair et al. [73] suggested that the internal loadings of each factor must exceed 0.6. As shown in Table 2, all internal loadings are greater than 0.70. Moreover, the internal loadings are clearly larger than the cross-loadings, suggesting the reliability of the data. To further evaluate the reliability of the measures, we computed the Cronbach's $\alpha$ for each construct, which is listed in Table 2. Bagozzi and Yi [74] suggested that the Cronbach's $\alpha$ of each construct must exceed the threshold value of 0.6 , while a recommended value for Cronbach's $\alpha$ is 0.7 or above [75]. As shown in Table 2, all Cronbach's $\alpha$ values are higher than the recommended value, indicating high construct reliability.

Table 2. Validity and reliability test.

\begin{tabular}{|c|c|c|c|c|c|c|c|c|}
\hline \multirow{2}{*}{ Construct } & & \multicolumn{7}{|c|}{ Factors } \\
\hline & & 1 & 2 & 3 & 4 & 5 & 6 & 7 \\
\hline \multirow{3}{*}{ Price concession } & PC1 & 0.87 & & & & & & \\
\hline & PC2 & 0.83 & & & & & & \\
\hline & PC3 & 0.79 & & & & & & \\
\hline \multirow{3}{*}{$\begin{array}{l}\text { Perceived } \\
\text { Innovation }\end{array}$} & PI1 & & 0.76 & & & & & \\
\hline & PI2 & & 0.78 & & & & & \\
\hline & PI3 & & 0.79 & & & & & \\
\hline \multirow{3}{*}{ Transaction Cost } & TC1 & & & 0.78 & & & & \\
\hline & TC2 & & & 0.74 & & & & \\
\hline & TC3 & & & 0.80 & & & & \\
\hline \multirow{3}{*}{ Performance Risk } & PR1 & & & & 0.78 & & & \\
\hline & PR2 & & & & 0.79 & & & \\
\hline & PR3 & & & & 0.87 & & & \\
\hline \multirow{4}{*}{$\begin{array}{l}\text { Perceived Net Goal } \\
\text { Attainment }\end{array}$} & PNGA1 & & & & & 0.75 & & \\
\hline & PNGA2 & & & & & 0.71 & & \\
\hline & PNGA3 & & & & & 0.78 & & \\
\hline & PNGA4 & & & & & 0.73 & & \\
\hline \multirow{4}{*}{ Satisfaction } & SF1 & & & & & & 0.74 & \\
\hline & SF2 & & & & & & 0.75 & \\
\hline & SF3 & & & & & & 0.78 & \\
\hline & SF4 & & & & & & 0.71 & \\
\hline \multirow{3}{*}{ Purchase Intention } & INT1 & & & & & & & 0.80 \\
\hline & INT2 & & & & & & & 0.85 \\
\hline & INT3 & & & & & & & 0.72 \\
\hline Cronbach's $\alpha$ & & 0.87 & 0.82 & 0.82 & 0.84 & 0.83 & 0.83 & 0.83 \\
\hline
\end{tabular}

Note: Coefficients less than 0.4 are unmarked. 
A confirmatory factor analysis (CFA) was further conducted to check the reliability and validity of the constructs. The results indicate a good fit between the data and the model. Specifically, $\chi 2(218)=424.322$, goodness of fit index $(\mathrm{GFI})=0.915$, norm fit index $(\mathrm{NFI})=0.905$, incremental fit index $(\mathrm{IFI})=0.951$, the comparison fit index $(\mathrm{CFI})=0.951$, and the root mean square error of approximation $($ RMSEA) $=0.049$. The CFA results are summarized in Table 3 . The $t$-value for each item is above 2, suggesting a sufficient convergent validity of the instrument [67]. The composite reliability (CR) of a construct assesses the extent to which its items measure it. The recommended level of CR is above 0.7 [76]. The results show that the $C R$ of each construct exceeds 0.8 , suggesting a high construct reliability. The average variance extracted (AVE) of a construct measures the variation explained by the latent variable to random measurement error, which is used for evaluating the convergent validity of the instrument. As shown in Table 3, the AVE of each construct is above the recommended benchmark of 0.5 [77], indicating a satisfactory convergent validity of the scales.

We used the Fornell-Larcker's criterion test to check discriminant validity of the measurement model [76]. According to the suggestions, the square root of the AVE for each construct should exceed its correlation coefficients with other constructs. As revealed in Table 4, this criterion is satisfied, suggesting a good discriminant validity of this model. Therefore, the measurement model possesses an adequate construct reliability, discriminant reliability, and convergent validity.

Finally, a Harmon one-factor test was performed to assess the common method bias [78]. In this study, the first principal component accounts for $25.918 \%$ of the explained variance, indicating that the common method bias does not threaten the overall analyses [79].

Table 3. Convergent and discriminant validity analysis.

\begin{tabular}{|c|c|c|c|c|c|c|}
\hline Construct & Indicator & Estimate & S.E. & t-value & AVE & CR \\
\hline \multirow{3}{*}{ Price Concession } & PC1 & 1.00 & & & 0.69 & 0.87 \\
\hline & PC2 & 0.98 & 0.05 & 18.61 & & \\
\hline & PC3 & 0.93 & 0.05 & 17.55 & & \\
\hline \multirow{3}{*}{ Perceived Innovation } & PI1 & 1.00 & & & 0.61 & 0.82 \\
\hline & PI2 & 1.05 & 0.07 & 14.17 & & \\
\hline & PI3 & 1.11 & 0.08 & 14.27 & & \\
\hline \multirow{3}{*}{ Transaction Cost } & TC1 & 1.00 & & & 0.60 & 0.82 \\
\hline & TC2 & 0.93 & 0.07 & 13.29 & & \\
\hline & TC3 & 1.02 & 0.07 & 13.83 & & \\
\hline \multirow{3}{*}{ Performance Risk } & PR1 & 1.00 & & & 0.66 & 0.85 \\
\hline & PR2 & 1.33 & 0.09 & 15.47 & & \\
\hline & PR3 & 1.66 & 0.10 & 16.25 & & \\
\hline \multirow{4}{*}{$\begin{array}{l}\text { Perceived Net Goal } \\
\text { Attainment }\end{array}$} & PNGA1 & 1.00 & & & 0.55 & 0.83 \\
\hline & PNGA2 & 0.95 & 0.07 & 13.26 & & \\
\hline & PNGA3 & 1.09 & 0.08 & 14.58 & & \\
\hline & PNGA4 & 1.00 & 0.07 & 13.66 & & \\
\hline \multirow{4}{*}{ Satisfaction } & SF1 & 1.00 & & & 0.55 & 0.83 \\
\hline & SF2 & 1.05 & 0.08 & 13.60 & & \\
\hline & SF3 & 1.07 & 0.08 & 13.98 & & \\
\hline & SF4 & 1.01 & 0.08 & 13.03 & & \\
\hline \multirow{3}{*}{ Purchase Intention } & INT1 & 1.00 & & & 0.63 & 0.83 \\
\hline & INT2 & 1.17 & 0.07 & 15.86 & & \\
\hline & INT3 & 0.83 & 0.06 & 14.26 & & \\
\hline
\end{tabular}


Table 4. Inter-construct correlations.

\begin{tabular}{lccccccc}
\hline Construct & PC & PI & TC & PR & PNGA & SF & INT \\
\hline PC & 0.832 & & & & & & \\
PI & 0.325 & 0.780 & & & & & \\
TC & 0.017 & 0.057 & 0.772 & & & & \\
PR & -0.082 & -0.063 & 0.438 & 0.812 & & & \\
PNGA & 0.484 & 0.583 & -0.182 & -0.027 & 0.742 & & \\
SF & 0.336 & 0.289 & 0.022 & -0.102 & 0.535 & 0.743 & \\
INT & 0.253 & 0.316 & -0.022 & -0.091 & 0.372 & 0.574 & 0.792 \\
\hline
\end{tabular}

Note: PC $=$ Price Concession; PI $=$ Perceived Innovation; $\mathrm{TC}=$ Transaction Cost $; \mathrm{PR}=$ Performance Risk; PNGA = Perceived Net Goal Attainment; SF = Satisfaction; INT = Purchase Intention .

\subsubsection{Hypotheses Testing}

By using AMOS (Version 19.0, AMOS, USA), the path coefficients and their significance levels of the structural model were computed. These results are summarized in Table 5, and the validated structural model is depicted as in Figure 2. First, we examine $H 1$ and $H 2$. H1, which assumes that price concession positively impacts PNGA, is supported with the path coefficient of 0.33 with the $t$-value $=6.17$ and $p<0.001$. $H 2$, which predicts a positive effect of the perceived innovation on PNGA, is supported with the path coefficient of 0.47 with $t$-value $=7.89$ and $p<0.001$. Thus, when fundraisers sell crowdfunding products/services at a discount and when their products/services are of value, consumers will perceive a high level of net goal attainment.

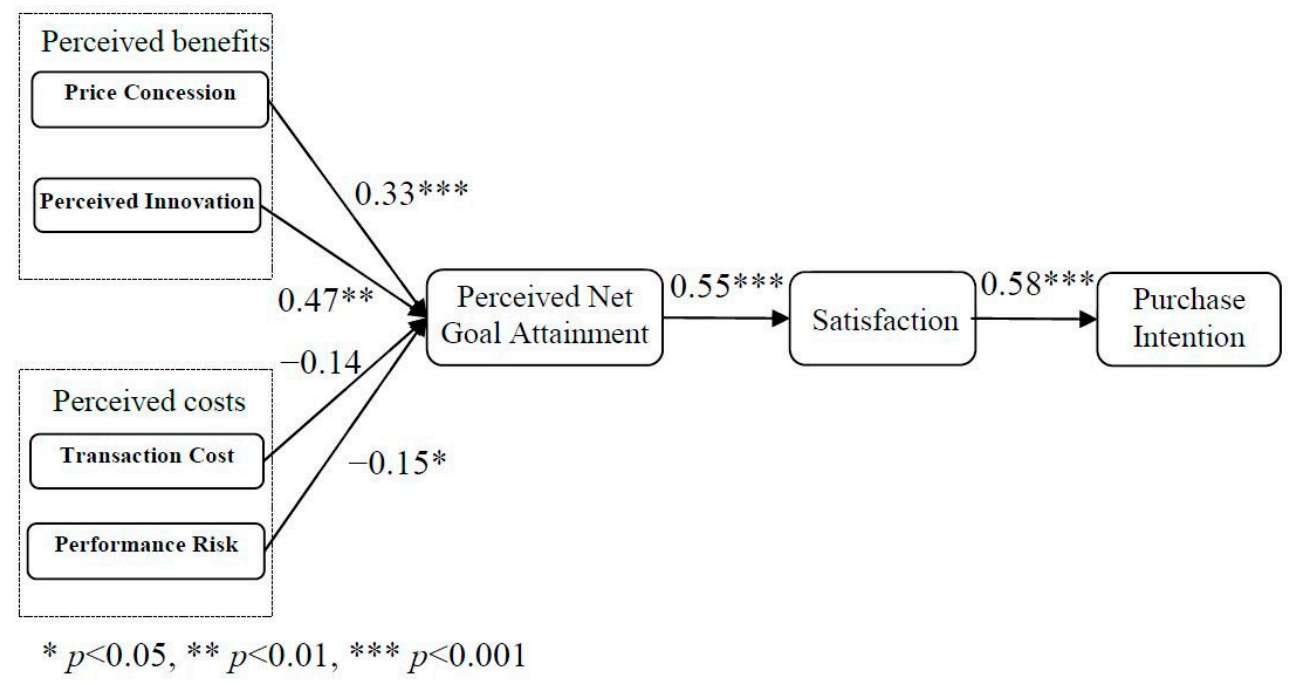

Figure 2. Estimation of the structural model.

Second, we check hypotheses regarding perceived costs (H3 and H4). As shown in Table 5, transaction cost exerts a negative effect on PNGA $(\beta=-0.14, t$-value $=-2.40, p<0.05)$, lending support to $H 3$. As for $H 4$, which predicts that performance risk negatively impacts PNGA, the path coefficient is -0.15 ( $t$-value $=-2.68, p<0.01)$. Hence, $\mathrm{H} 4$ is also supported. These results indicate that consumers will perceive a lower level of net goal attainment when they feel that purchasing crowdfunding products/services is associated with a higher level of costs, in terms of either transaction cost or performance risk.

Finally, we examine $H 5$ and $H 6$, which are relevant to relationships between PNGA, satisfaction, and purchase intention. PNGA $(\beta=0.55, t$-value $=8.55, p<0.001)$ has a positive and strong effect on satisfaction, lending support to $H 5$. $H 6$, which predicts that satisfaction exerts a positive effect on purchase intention, is perfectively supported $(\beta=0.58, t$-value $=8.55, p<0.001)$. Therefore, consumers' 
perceived net goal attainment, that weighs their perceived benefits against perceived costs, indirectly influences their purchase intention toward products/services in crowdfunding markets.

Table 5. Standardized coefficients and t-value for each path.

\begin{tabular}{|c|c|c|c|c|}
\hline Path & Hypotheses & $\begin{array}{c}\text { Standardized } \\
\text { Coefficient }\end{array}$ & $t$-Value & Support \\
\hline $\mathrm{H} 1$ & $\mathrm{PC} \rightarrow \mathrm{PNGA}$ & 0.33 & $6.17^{* * *}$ & Yes \\
\hline $\mathrm{H} 2$ & $\mathrm{PI} \rightarrow \mathrm{PNGA}$ & 0.47 & $7.89^{* * *}$ & Yes \\
\hline $\mathrm{H} 3$ & $\mathrm{TC} \rightarrow \mathrm{PNGA}$ & -0.14 & $-2.40^{*}$ & Yes \\
\hline $\mathrm{H} 4$ & $\mathrm{PR} \rightarrow \mathrm{PNGA}$ & -0.15 & $-2.68^{* *}$ & Yes \\
\hline H5 & $\mathrm{PNGA} \rightarrow \mathrm{SF}$ & 0.55 & $8.55^{* * *}$ & Yes \\
\hline H6 & $\mathrm{SF} \rightarrow \mathrm{INT}$ & 0.58 & $9.23^{* * *}$ & Yes \\
\hline
\end{tabular}

\subsection{Artificial Neural Network (ANN) Analysis}

Artificial neural network (ANN) has been increasingly applied to predicting the relative importance of the predictors of a dependent variable, particularly in the IS field [80-84]. Researchers have suggested a two-staged SEM-ANN approach $[80,81,84]$ in which the results of an ANN analysis are compared with the results of an SEM analysis in order to ascertain the robustness of overall results. Following the suggested procedure of this two-staged approach, a dependent variable was taken as the output of an ANN network, and its significant predictors based on an ANN analysis were taken as the input when building the neural network model. The ANN model for this research is shown in Figure 3 . We used a multi-layer perceptron of ANN to analyze the model with sigmoid function via SPSS [82]. A 10 -fold cross-validation approach with $90 \%$ of the data for training and $10 \%$ for testing was applied in checking the predictive accuracy of the ANN model [83]. All parameters were in accordance with those suggested by Tan, Ooi, Leong, and Lin [84]. The root mean square of error (RMSE), which was averaged over ten networks, was used to evaluate predictive accuracy of the model. Table 6 indicates that the RMSE values range from 0.083 to 0.095 for training data, and they range from 0.071 to 0.113 for testing data. Therefore, the ANN model possesses high predictive accuracy, and the relationships between the predictors and the dependent variable can be captured by the network model reliably [81].

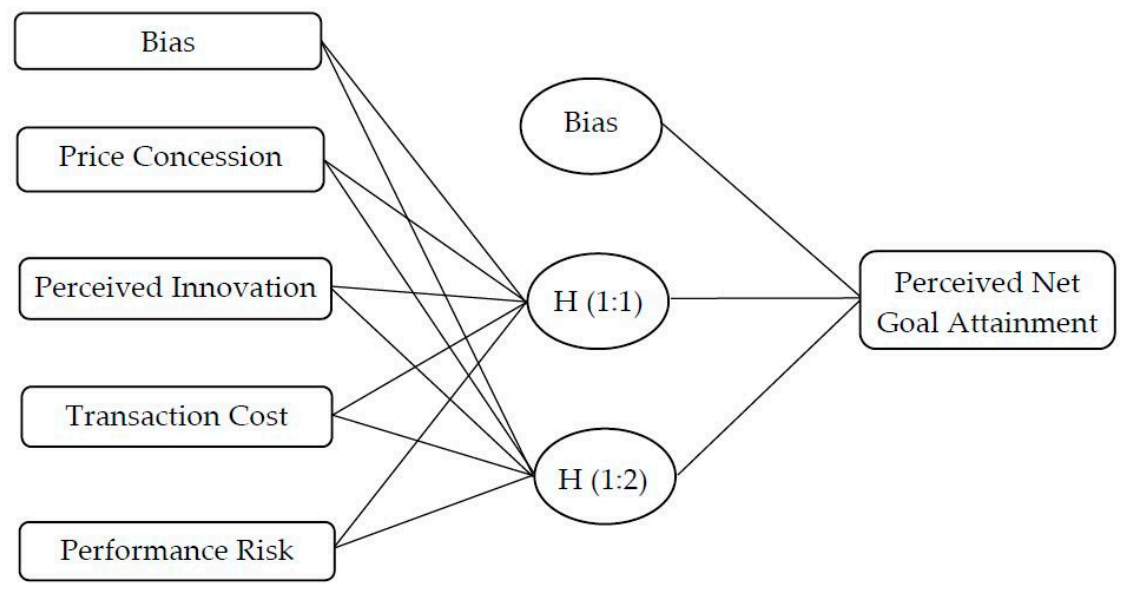

Hidden layer activation function: Sigmoid

Output layer activation function: Sigmoid

Figure 3. A depiction of the artificial neural network (ANN) model. 
Table 6. The root mean square of error (RMSE) values of the neural network model.

\begin{tabular}{ccc}
\hline Network & Training & Testing \\
\hline 1 & 0.086 & 0.113 \\
2 & 0.090 & 0.079 \\
3 & 0.095 & 0.094 \\
4 & 0.087 & 0.100 \\
5 & 0.087 & 0.075 \\
6 & 0.083 & 0.084 \\
7 & 0.092 & 0.071 \\
8 & 0.094 & 0.085 \\
9 & 0.087 & 0.103 \\
10 & 0.089 & 0.074 \\
Mean RMSE & 0.089 & 0.088 \\
Standard deviation & 0.004 & 0.014 \\
\hline
\end{tabular}

Furthermore, a sensitivity analysis was performed to estimate the relative importance of the predictors. Following previous literature, the average importance of each input variable was calculated, and the normalized relative importance of each one was therefore obtained [81]. As shown in Table 7 , the relative importance of perceived innovation is significantly more than that of price concession. Therefore, perceived innovation is the most important factor, and price concession is of secondary importance for PNGA, which is consistent with the SEM results. The results also suggest that perceived costs have less importance than perceived benefits.

Table 7. Normalized variable importance.

\begin{tabular}{lccc}
\hline \multicolumn{1}{c}{ Variable } & Relative Importance & $\begin{array}{c}\text { Normalized Relative } \\
\text { Importance (\%) }\end{array}$ & Ranking \\
\hline Perceived innovation & 0.472 & 100.00 & 1 \\
Price concession & 0.290 & 61.40 & 2 \\
Transaction cost & 0.142 & 30.10 & 3 \\
Performance risk & 0.097 & 20.53 & 4 \\
\hline
\end{tabular}

\section{Discussion}

In light of GAT and research related to crowdfunding and online shopping, we examined how backers develop a purchase intention toward a product/service in crowdfunding markets from a cost-benefit perspective. By using a two-staged SEM-ANN analysis, this study identified the relative importance of two critical benefit factors (price concession and perceived innovation) and two critical cost factors (transaction cost and performance risk) in shaping consumers' intention.

First, perceived benefits were shown to have a positive effect on PNGA, consistent with previous findings [15]. We have advanced previous work by subdividing perceived benefit into two critical factors. More specifically, we found that both price concession and perceived innovation are important for consumers to make their decision to purchase products/services in crowdfunding markets. Varied promotional strategies in respect to price are effective to attract and retain consumers in online retailing [85,86]. Wei, Wang, Xue, and Chen [42] revealed that price concession is one of the main factors affecting online purchase intention toward fruits. Our findings further suggest that the effect of price concession on purchase intention can be extended to the context of crowdfunding products/services for China's consumers. Truong et al. [87] found that the more innovative a product, the higher consumers' perceived value. More importantly, previous literature has evidenced the role of crowdfunding in fostering innovations and turning them into marketable products/services [44,45]. In line with the extant literature, our findings further evidence the importance of crowdfunding-driven innovation from a consumer's perspective. Therefore, fundraisers which provide innovative products/services can attain a foothold in an increasingly competitive crowdfunding market. Remarkably, the path coefficient 
associated with perceived innovation $(\beta=0.47, p<0.001)$ was higher than that associated with price discounting ( $\beta=0.33, p<0.001$ ) in the structural equation model, and the relative importance of perceived innovation (0.472) was higher than that of price concession (0.330) in the artificial neural network model. The same result in regard to the relative importance of price concession and perceived innovation was obtained by using two different approaches. Therefore, we have tentatively concluded that perceived innovation is more important than price concession in shaping consumer purchase decisions in the context of crowdfunding products/services.

Second, perceived costs exert a negative effect on PNGA, which thereby indirectly influences consumer purchase intention. This finding suggests that PNGA decreases when perceived transaction cost and performance risk increase. However, the SEM analysis showed both the two path coefficients are relatively small, which indicates that the negative effects are relatively weak. Here, we provide a basic explanation for these results. With the popularization of e-commerce, shopping online has become quite normal for many people. An online information search is easy and does not greatly increase work for most e-shoppers. As such, searching the web for relevant information regarding crowdfunding products/services and fundraisers would be easy for potential buyers. Meanwhile, we reported a weak effect of consumers' perceived performance risk on their purchase intention. Mollick and Nanda [88] found that crowds can be as rational as experts in a study of funding the arts. Our finding is consistent with their findings in that crowds have the wisdom to avoid risk in crowdfunding. We also noticed that the finding might be partially due to the research context. In China, most popular crowdfunding platforms are invested largely and operated by China's e-commerce leaders, who have already established a high reputation among the public. Therefore, most consumers might think that these platforms have a strict inspection system toward the fundraisers and their projects. Considering that consumers' trust reduces their perceived uncertainty in online trading, particularly in crowdfunding [89], study subjects might place their trust in the platform, thus lowering their perceived performance risk. Interestingly, by analyzing the grouped data of backers of Taiwan's FlyingV platform, Zhao, Chen, Wang, and Chen [15] suggested that for those with positive risk preference, perceived risk has a positive effect on purchase intention, leading to an opposite result to ours. They explained that high risk could bring high returns, which might stimulate the willingness to invest. On the contrary, for risk averters, the lower the perceived risk, the stronger the willingness to buy, which is consistent with our findings. In this study, the study sample was randomly selected and was not grouped in terms of risk preference. Together, these results might stimulate further exploration toward the relationship between risk aversion and behavioral intentions in crowdfunding.

Third, the present work shows that satisfaction mediates the relationship between PNGA and purchase intention in reward-based crowdfunding markets. PNGA is a trade-off between perceived benefits and perceived costs. Consistent with previous studies [17,32,34], PNGA significantly exerts a positive impact on satisfaction. Furthermore, the present study confirms the relationship between satisfaction and behavioral intentions such as purchase intention $[58,63]$ and loyalty $[59,60,64-66]$. Obviously, in order to turn browsers into backers, the central tenet for fundraisers is to make browsers satisfied.

\section{Implications and Limitations}

\subsection{Theoretical Implications}

Our research advances the understanding of factors influencing backers' funding intention from a cost-benefit perspective. Specifically, such a funding intention is more closely related to purchasing a crowdfunding product/service. The theoretical implications are two-fold at least.

First, GAT that is contingent upon a cost-benefit framework has been successfully applied in exploring backers' funding intention. Despite a number of both benefits and costs that influence behavioral intentions toward crowdfunding that have been identified, how these two forces jointly play a role has seldom been explored. We found that PNGA, which is the tradeoff between benefits 
and costs, indirectly influences funding intention through the mediation of satisfaction. The results highlight the importance of understanding backers' funding intention within the cost-benefit umbrella and, therefore, contribute to the crowdfunding literature.

Second, the role of perceived benefits/costs in a systematic cost-benefit framework has been identified. Compared with an online shopping journey, consumers have to pay much more attention to specific information in regard to a crowdfunding project [90], such as fundraising background, duration, and the remaining days before the deadline. Moreover, crowdfunding, as an express fundraising tool for small- and medium-size businesses, may encounter potential risks such as malicious fraud and patent infringement, and consumers have to take various risks into account when purchasing a crowdfunding product/service [15]. These two types of costs could become a barrier to build a trusting belief toward funding [14]. However, according to the two-staged analyses of the relative importance between major benefits and costs, we reported a relatively weak effect in regard to either performance risk or transaction cost. These results contribute to the crowdfunding literature by adding useful knowledge that quantitatively weighs the relative importance of consumers' perceived benefits and costs in purchasing reward-based crowdfunding products/services.

\subsection{Managerial Implications}

It is worth mentioning again that these findings might help small- and medium-sized businesses orient themselves toward the sustainable development by utilizing reward-based crowdfunding $[11,91,92]$. This research provides several insights into how reward-based crowdfunding can be fully utilized for fundraisers who aim at selling their innovative products/services as well as other roles that are active in crowdfunding markets.

For fundraisers, while their ultimate goal is to increase the innovation or novelty of their products/services, they also need to make consumers simultaneously get the point. Considering that many innovative products/services are advertised and sold on crowdfunding platforms during pilot production stages, consumers know little information through other channels. As such, fundraisers could expand social media channels for advertisement and promotion since social media are free and open. Another important suggestion for fundraisers is that they should manipulate their pricing strategy. Our results show that, as an effective means of promotion, price concession has a remarkable effect on consumer purchase intention. Therefore, a tempting price reduction could increase people's willingness to purchase effectively, and the fundraisers could adopt a differentiated pricing strategy. For example, a higher price discounting rate can be given to earlier buyers, and the rate could possibly increase with the amount of increasing purchases. In light of the findings regarding perceived costs, fundraisers need to disclose information about the process of their projects and respond to their potential backers in time, thus alleviating consumers' uncertainty. It is undoubted that the quality of the products/services ought to be firmly guaranteed.

For the system designers and managers of crowdfunding platforms, it is of importance to provide technical features and support as many as possible to help fundraisers attracting potential investors. With increasingly pervasive smartphones, the support for mobile access and the amelioration of user experiences in the mobile context is warranted. In light of the importance of online review systems, we suggest that the review systems of crowdfunding websites, particularly reward-based ones, could be improved by considering the uniqueness that comes with purchasing innovative products/services from such platforms. During pre-purchase stages, consumers have an option to predict a project's performance, respecting innovation, risk, and transaction time. Upon receiving the product or service, consumers could make more objective evaluations. After using it, they could upload text/picture/video reviews regarding their use experience. The consumer generated data could be utilized to inspect the various misconduct of fundraisers so that consumers can be less threatened by performance risk. 


\subsection{Limitations and Future Research Directions}

Though this study provides meaningful implications, it has limitations that are worth noting. First, we measured subjects' behavioral intentions rather than actual investment/funding behaviors. By trawling data on crowdfunding sites, the efficacy of theoretical models can be authentically examined. Second, considering that the present study revealed that perceived innovation is the most important factor for consumers who purchase crowdfunding products/services, and that previous literature identified consumer innovativeness as a critical individual trait that influences their intentions toward using and adopting new products/services [93], a finer-grained understanding of the effect of consumer innovativeness on purchase intention in crowdfunding is warranted. Third, the cost-benefit framework of this work includes essential influencing factors, and more variables that are either positive or negative could be incorporated in order to have a more comprehensive understanding. Forth, the empirical data in this study were obtained from China's consumers. Thus, caution must be taken when generalizing the results to other countries because of cultural differences. Future research might conduct a cross-country comparison study so that cultural/national differences could be identified. Finally, considering that many fundraisers also employ social media marketing and many potential backers read social media comments/reviews [13], the role of social-media-based information diffusion in shaping consumers' behavioral intentions could be taken into further consideration.

\section{Conclusions}

Crowdfunding opens a new avenue for fund collection and has attracted much attention from many underfunded enterprises and startups. The recent phenomenon of marketing and selling products/services in reward-based markets deserves research attention regarding its significance in the sustainable growth of those developing ventures. Grounded in GAT, we applied a cost-benefit framework to the probing of consumer purchase intention toward crowdfunding products/services while considering consumers' both benefits and costs. These findings contribute to the literature by highlighting the necessity of weighing both benefits and costs within a unifying framework and providing quantitative knowledge of the relative importance of these factors when scrutinizing consumer purchase intention toward crowdfunding products/services. We offer practitioners the suggestion that the perceived novelty of products/services is the most critical factor for their PNGA, the subsequent satisfaction, and purchase intention. Meanwhile, consumers' perceived costs that come with purchasing crowdfunding products/services, such as transaction cost and performance risk, weakly impact their PNGA, implying that increasing their perceived benefits could be more efficacious than decreasing their perceived costs for practitioners. In a nutshell, this research provides insights into the mechanisms underlying consumer purchase intention toward products/services in reward-based crowdfunding markets.

Author Contributions: Conceptualization, Y.L.; methodology, Y.L.; data curation, R.W. and Z.Z.; writing一original draft preparation, Z.Z.; writing—review and editing, Y.L. and Y.C.; project administration, Y.L.

Funding: This research was funded by the Humanity and Social Science foundation of Ministry of Education, grant number 18YJA630058 and by the National Natural Science Foundation of China, grant number 71701182.

Conflicts of Interest: The authors declare no conflict of interest. 


\section{Appendix A}

Table A1. List of survey items.

\begin{tabular}{|c|c|c|c|}
\hline Construct & Item & Measurement Items & References \\
\hline \multirow[t]{3}{*}{ Price Concession (PC) } & PC1 & $\begin{array}{l}\text { Products/Services on crowdfunding platforms are often } \\
\text { cheaper than those on other platforms or those via } \\
\text { offline channels. }\end{array}$ & \multirow[t]{3}{*}{ [42] } \\
\hline & PC2 & $\begin{array}{l}\text { The price of crowdfunding products/services is favorable } \\
\text { and attractive. }\end{array}$ & \\
\hline & PC3 & Crowdfunding products/services are often sold at a discount. & \\
\hline \multirow{3}{*}{ Perceived innovation (PI) } & PV1 & Crowdfunding products/services are innovative. & \multirow{3}{*}[15,67]{} \\
\hline & PV2 & $\begin{array}{l}\text { I feel that crowdfunding products/services are associated with } \\
\text { a high level of innovation. }\end{array}$ & \\
\hline & PV3 & I perceive crowdfunding products/services as innovation. & \\
\hline \multirow{3}{*}{ Transaction cost (TC) } & TC1 & $\begin{array}{l}\text { I spend a lot of effort searching for relevant information when } \\
\text { purchasing crowdfunding products/services. }\end{array}$ & \multirow{3}{*}[50,51]{} \\
\hline & TC2 & I spend a lot of time contacting the seller. & \\
\hline & TC3 & $\begin{array}{l}\text { When purchasing crowdfunding products/services, I spend a } \\
\text { lot of effort monitoring the ongoing process of fundraising. }\end{array}$ & \\
\hline \multirow{3}{*}{ Performance Risk (PR) } & PR1 & $\begin{array}{l}\text { I worry about whether crowdfunding products/services will } \\
\text { not provide the level of benefits I expect. }\end{array}$ & \multirow{3}{*}{ [56] } \\
\hline & PR2 & $\begin{array}{l}\text { It is uncertain that crowdfunding products/services will } \\
\text { satisfy me. }\end{array}$ & \\
\hline & PR3 & $\begin{array}{l}\text { It is uncertain that crowdfunding products/services will } \\
\text { perform the functions/utilities that were described in } \\
\text { the advertisement. }\end{array}$ & \\
\hline \multirow{4}{*}{$\begin{array}{l}\text { Perceived net goal } \\
\text { Attainment (PNGA) }\end{array}$} & PNGA1 & $\begin{array}{l}\text { Purchasing crowdfunding products/services is worth the } \\
\text { effort that I put into it. }\end{array}$ & \multirow{4}{*}[17,31]{} \\
\hline & PNGA2 & $\begin{array}{l}\text { The things that are accomplished in purchasing crowdfunding } \\
\text { products/services warrant my effort. }\end{array}$ & \\
\hline & PNGA3 & $\begin{array}{l}\text { The results of purchasing crowdfunding products/services are } \\
\text { worth the time I invest. }\end{array}$ & \\
\hline & PNGA4 & $\begin{array}{l}\text { The value I receive from purchasing products/services in } \\
\text { crowdfunding markets activity justifies my efforts. } \\
\text { How do you feel about your overall experience with } \\
\text { crowdfunding products/services? }\end{array}$ & \\
\hline \multirow{4}{*}{ Satisfaction (SF) } & SF1 & (Strongly dissatisfied to strongly satisfied). & \multirow{4}{*}[17,68,69]{} \\
\hline & SF2 & (Strongly displeased to strongly pleased). & \\
\hline & SF3 & (Strongly frustrated to strongly contended). & \\
\hline & SF4 & (Strongly terrible to strongly delighted). & \\
\hline \multirow{3}{*}{ Purchase Intention (PI) } & PI1 & $\begin{array}{l}\text { The likelihood that I would pay for crowdfunding } \\
\text { products/services is: (very low to very high). }\end{array}$ & \multirow{3}{*}[70,71]{} \\
\hline & PI2 & $\begin{array}{l}\text { My willingness to buy crowdfunding products/services is: } \\
\text { (very low to very high). }\end{array}$ & \\
\hline & PI3 & $\begin{array}{l}\text { In near future, I would consider purchasing } \\
\text { crowdfunding products/services. }\end{array}$ & \\
\hline
\end{tabular}

\section{References}

1. Best, J.; Neiss, S.; Swart, R.; Lambkin, A.; Raymond, S. Crowdfunding's potential for the developing world; InfoDev: Washington, DC, USA, 2013.

2. Mollick, E. The dynamics of crowdfunding: An exploratory study. J. Bus. Ventur. 2014, 29, 1-16. [CrossRef]

3. Xiao, S.; Yue, Q. Investors' inertia behavior and their repeated decision-making in online reward-based crowdfunding market. Decis. Support Syst. 2018, 111, 101-112. [CrossRef]

4. Ordanini, A.; Miceli, L.; Pizzetti, M.; Parasuraman, A. Crowd-funding: Transforming customers into investors through innovative service platforms. J. Serv. Manag. 2011, 22, 443-470. [CrossRef]

5. Yang, Q.; Lee, Y.-C. Influencing factors on the lending intention of online peer-to-peer lending: Lessons from renrendai. com. J. Inf. Syst. 2016, 25, 79-110.

6. Althoff, T.; Leskovec, J. Donor retention in online crowdfunding communities: A case study of DonorsChoose.org. In Proceedings of the 24th International Conference on World Wide Web; International World Wide Web Conferences Steering Committee: Florence, Italy, 1981; pp. 34-44. 
7. Terpstra, D.E.; Olson, P.D. Entrepreneurial start-up and growth: A classification of problems. Entrep. Theory Pract. 1993, 17, 5-20. [CrossRef]

8. De la Torre, A.; Soledad Martinez Peria, M.; Schmukler, S.L. Bank Involvement with SMEs: Beyond Relationship Lending; The World Bank: Washington, DC, USA, 2008.

9. Cordova, A.; Dolci, J.; Gianfrate, G. The determinants of crowdfunding success: Evidence from technology projects. Procedia Soc. Behav. Sci. 2015, 181, 115-124. [CrossRef]

10. Belleflamme, P.; Lambert, T.; Schwienbacher, A. Crowdfunding: Tapping the right crowd. Soc. Sci. Electron. Publishing 2011, 29, 585-609.

11. Petruzzelli, A.M.; Natalicchio, A.; Panniello, U.; Roma, P. Understanding the crowdfunding phenomenon and its implications for sustainability. Technol. Forecast. Soc. 2019, 141, 138-148. [CrossRef]

12. Brown, T.E.; Boon, E.; Pitt, L.F. Seeking funding in order to sell: Crowdfunding as a marketing tool. Bus Horiz. 2017, 60, 18-195. [CrossRef]

13. Crosetto, P.; Regner, T. It's never too late: Funding dynamics and self pledges in reward-based crowdfunding. Res. Policy 2018, 47, 1463-1477. [CrossRef]

14. Liang, T.-P.; Wu, S.P.-J.; Huang, C.-C. Why funders invest in crowdfunding projects: Role of trust from the dual-process perspective. Inform Manage-Amster 2019, 56, 70-84. [CrossRef]

15. Zhao, Q.; Chen, C.D.; Wang, J.L.; Chen, P.C. Determinants of backers' funding intention in crowdfunding: Social exchange theory and regulatory focus. Telemat. Inform. 2017, 34, 370-384. [CrossRef]

16. King, I.M. A Theory for Nursing Systems, Concepts, Process; Delmar Pub: Delmar, NY, USA, 1981.

17. Sun, Y.; Fang, Y.; Lim, K.H. Understanding knowledge contributors' satisfaction in transactional virtual communities: A cost-benefit trade-off perspective. Inf. Manag. 2014, 51, 441-450. [CrossRef]

18. Kuppuswamy, V.; Bayus, B.L. Crowdfunding Creative Ideas: The Dynamics of Project Backers in Kickstarter. Available online: https:/funginstitute.berkeley.edu/wp-content/uploads/2013/11/Crowdfunding_Creative_ Ideas.pdf (accessed on 27 June 2019).

19. Kang, L.; Jiang, Q.; Tan, C.-H. Remarkable advocates: An investigation of geographic distance and social capital for crowdfunding. Inf. Manag. 2017, 54, 336-348. [CrossRef]

20. Zhang, H.; Chen, W. Crowdfunding technological innovations: Interaction between consumer benefits and rewards. Available online: https://www.researchgate.net/publication/325415617_Crowdfunding_Technological_ Innovations_Interaction_between_Consumer_Benefits_and_Rewards (accessed on 27 June 2019).

21. Parhankangas, A.; Renko, M. Linguistic style and crowdfunding success among social and commercial entrepreneurs. Journal of Business Venturing 2017, 32, 215-236. [CrossRef]

22. Wang, N.; Li, Q.; Liang, H.; Ye, T.; Ge, S. Understanding the importance of interaction between creators and backers in crowdfunding success. Electron. Commer. Res. Appl. 2018, 27, 106-117. [CrossRef]

23. Moon, Y.; Hwang, J. Crowdfunding as an alternative means for funding sustainable appropriate technology: Acceptance determinants of backers. Sustainability 2018, 10, 1456. [CrossRef]

24. Kang, M.; Gao, Y.; Tao, W.; Zheng, H. Understanding the determinants of funders' investment intentions on crowdfunding platforms: A trust-based perspective. Ind. Manag. Data Syst. 2016, 116, 1800-1819. [CrossRef]

25. Ho, H.Y.; Lin, P.C.; Lu, M.H. Effects of online crowdfunding on consumers' perceived value and purchase intention. Anthropologist 2014, 17, 837-844. [CrossRef]

26. Bretschneider, U.; Leimeister, J.M. Not just an ego-trip: Exploring backers' motivation for funding in incentive-based crowdfunding. J. Strateg. Inf. Syst. 2017, 26, 246-260. [CrossRef]

27. Herzenstein, M.; Dholakia, U.M.; Andrews, R.L. Strategic herding behavior in peer-to-peer loan auctions. J. Interact. Mark. 2011, 25, 27-36. [CrossRef]

28. Davis, B.C.; Hmieleski, K.M.; Webb, J.W.; Coombs, J.E. Funders' positive affective reactions to entrepreneurs' crowdfunding pitches: The influence of perceived product creativity and entrepreneurial passion. J. Bus. Ventur. 2017, 32, 90-106. [CrossRef]

29. Du, Z.; Li, M.X.; Wang, K.L. "The more options, the better?" Investigating the impact of the number of options on backers' decisions in reward-based crowdfunding projects. Inform Manage-Amster 2019, 56, 429-444. [CrossRef]

30. King, I.M. King's theory of goal attainment. Nurs. Sci. Q. 1992, 5, 19-26. [CrossRef]

31. Briggs, R.O.; Reinig, B.A.; de Vreede, G.-J. Meeting satisfaction for technology-supported groups: An empirical validation of a goal-attainment model. Small Group Res. 2006, 37, 585-611. [CrossRef] 
32. Reinig, B.A. Toward an understanding of satisfaction with the process and outcomes of teamwork. J. Manage. Inform. Syst. 2003, 19, 65-83.

33. Orsingher, C.; Marzocchi, G.L.; Valentini, S. Consumer (goal) satisfaction: A means-ends chain approach. Psychol. Market. 2011, 28, 730-748. [CrossRef]

34. Heitmann, M.; Lehmann, D.R.; Herrmann, A. Choice goal attainment and decision and consumption satisfaction. J. Mark. Res. 2007, 44, 234-250. [CrossRef]

35. Monroe, K.B.; Chapman, J.D. Framing effects on buyers' subjective product evaluations. Adv. Consum. Res. 1987, 14, 193-197.

36. Moore, D.J.; Olshavsky, R.W. Brand choice and deep price discounts. Psychol. Mark. 1989, 6, 181-196. [CrossRef]

37. Reibstein, D.J. What attracts customers to online stores, and what keeps them coming back? J. Acad. Mark. Sci. 2002, 30, 465. [CrossRef]

38. Jiang, Y.; Liu, Y. Optimization of online promotion: A profit-maximizing model integrating price discount and product recommendation. Int. J. Inf. Technol. Decis. Mak. 2012, 11, 961-982. [CrossRef]

39. Raghubir, P.; Inman, J.J.; Grande, H. The three faces of consumer promotions. Calif. Manag. Rev. 2004, 46, 23-42. [CrossRef]

40. Teng, L. A comparison of two types of price discounts in shifting consumers' attitudes and purchase intentions. J. Bus. Res. 2009, 62, 14-21. [CrossRef]

41. Biswas, A.; Pullig, C.; Krishnan, B.C.; Burton, S. Consumer evaluation of reference price advertisements: Effects of other brands' prices and semantic cues. J. Public Policy Mark. 1999, 18, 52-65. [CrossRef]

42. Wei, Y.; Wang, C.; Xue, H.; Chen, F. Online purchase intention of fruits: Antecedents in an integrated model based on technology acceptance model and perceived risk theory. Front. Psychol. 2018, 9, 1521. [CrossRef]

43. Yao, H.; Zhang, Y. Research on influence factors of crowdfunding. Int. Bus. Manag. 2014, 9, $27-31$.

44. Mollick, E.; Robb, A. Democratizing innovation and capital access: The role of crowdfunding. Calif. Manag. Rev. 2016, 58, 72-87. [CrossRef]

45. Stanko, M.A.; Henard, D.H. Toward a better understanding of crowdfunding, openness and the consequences for innovation. Res. Policy 2017, 46, 784-798. [CrossRef]

46. Scholz, N. The Relevance of Crowdfunding: The Impact on the Innovation Process of Small Entrepreneurial Firms; Springer: Berlin, Germany, 2015.

47. Veryzer, R.W., Jr. Discontinuous innovation and the new product development process. J. Prod. Innov. Manag. 1998, 15, 304-321. [CrossRef]

48. Betz, F. Managing technological innovation: competitive advantage from change; John Wiley \& Sons: Hoboken, NJ, USA, 2003.

49. Higgins, J.M. Innovation: the core competence. Plan. Rev. 1995, 23, 32-36. [CrossRef]

50. Teo, T.S.; Yu, Y. Online buying behavior: a transaction cost economics perspective. Omega 2005, 33, 451-465. [CrossRef]

51. Yen, C.; Hsu, M.-H.; Chang, C.-M. Exploring the online bidder's repurchase intention: A cost and benefit perspective. Inf. Syst. e-Bus. Manag. 2013, 11, 211-234. [CrossRef]

52. Devaraj, S.; Fan, M.; Kohli, R. Examination of online channel preference: using the structure-conduct-outcome framework. Decis. Support Syst. 2006, 42, 1089-1103. [CrossRef]

53. Kim, Y.G.; Li, G. Customer satisfaction with and loyalty towards online travel products: a transaction cost economics perspective. Tour. Econ. 2009, 15, 825-846. [CrossRef]

54. Griffin, A.; Viehland, D. Demographic factors in assessing perceived risk in online shopping. In Proceedings of the 13th International Conference on Electronic Commerce, Liverpool, UK, 3-5 August 2011; p. 9.

55. Chen, Z.; Dubinsky, A.J. A conceptual model of perceived customer value in e-commerce: A preliminary investigation. Psychol Mark. 2003, 20, 323-347. [CrossRef]

56. Yang, H.; Yu, J.; Zo, H.; Choi, M. User acceptance of wearable devices: An extended perspective of perceived value. Telemat. Inform. 2016, 33, 256-269. [CrossRef]

57. Hong, I.B.; Cha, H.S. The mediating role of consumer trust in an online merchant in predicting purchase intention. Int. J. Inform. Manage. 2013, 33, 927-939. [CrossRef]

58. Oliver, R.L. A cognitive model of the antecedents and consequences of satisfaction decisions. J. Mark. Res. 1980, 17, 460-469. [CrossRef] 
59. Hsu, S.-H.; Chen, W.-H.; Hsieh, M.-J. Robustness testing of PLS, LISREL, EQS and ANN-based SEM for measuring customer satisfaction. Total. Qual. Manag. Bus. Excell. 2006, 17, 355-372. [CrossRef]

60. Reyes-Menendez, A.; Palos-Sanchez, P.R.; Saura, J.R.; Martin-Velicia, F. Understanding the influence of wireless communications and Wi-Fi access on customer loyalty: A behavioral model system. Wirel. Commun. Mob. Comput. 2018, 2018, 1-16. [CrossRef]

61. Xu, B.; Zheng, H.; Xu, Y.; Wang, T. Configurational paths to sponsor satisfaction in crowdfunding. J. Bus. Res. 2016, 69, 915-927. [CrossRef]

62. Zheng, H.; Xu, B.; Wang, T.; Xu, Y. An empirical study of sponsor satisfaction in reward-based crowdfunding. J. Electron. Commer. Res. 2017, 18, 269.

63. Ranaweera, C.; Bansal, H.; McDougall, G. Web site satisfaction and purchase intentions: Impact of personality characteristics during initial web site visit. Manag. Serv. Qual. 2008, 18, 329-348. [CrossRef]

64. Oliver, R.L. Whence Consumer Loyalty? J. Mark. 1999, 63, 33-44. [CrossRef]

65. Ju Rebecca Yen, H.; Gwinner, K.P. Internet retail customer loyalty: the mediating role of relational benefits. Int. J. Serv. Ind. Manag. 2003, 14, 483-500. [CrossRef]

66. Pereira, H.G.; de Fátima Salgueiro, M.; Rita, P. Online purchase determinants of loyalty: The mediating effect of satisfaction in tourism. J. Retail. Consum. Serv. 2016, 30, 279-291. [CrossRef]

67. Jung, H.S.; Kim, K.H.; Lee, C.H. Influences of perceived product innovation upon usage behavior for MMORPG: Product capability, technology capability, and user centered design. J. Bus. Res. 2014, 67, 2171-2178. [CrossRef]

68. Spreng, R.A.; Mackenzie, S.B.; Olshavsky, R.W. A reexamination of the determinants of consumer satisfaction. J. Mark. 1996, 60, 15-32. [CrossRef]

69. Bhattacherjee, A. Understanding information systems continuance: An expectation-confirmation model. MIS Quart. 2001, 25, 351-370. [CrossRef]

70. Dodds, W.B.; Monroe, K.B.; Grewal, D. Effects of price, brand, and store information on buyers' product evaluations. J. Mark. Res. 1991, 28, 307-319. [CrossRef]

71. Chu, C.-W.; Lu, H.-P. Factors influencing online music purchase intention in Taiwan: An empirical study based on the value-intention framework. Internet Research 2007, 17, 139-155. [CrossRef]

72. Hew, T.-S.; Kadir, S.L.S.A. Understanding cloud-based VLE from the SDT and CET perspectives: Development and validation of a measurement instrument. Comput Educ 2016, 101, 132-149. [CrossRef]

73. Hair, J.; Anderson, R.E.; Tatham, R.; Black, W. Multivariate Data Analysis; Prentice Hall: Saddle River, NJ, USA, 1995.

74. Bagozzi, R.P.; Yi, Y. On the evaluation of structural equation models. J. Acad. Mark. Sci. 1988, 16, 74-94. [CrossRef]

75. Nunnally, J.C.; Bernstein, I.H. Psychometric Theory. Am. Educ. Res. J. 1978, 5, 83.

76. Fornell, C.; Larcker, D.F. Evaluating structural equation models with unobservable variables and measurement error. J. Mark. Res. 1981, 18, 39-50. [CrossRef]

77. Netemeyer, R.G.; Johnston, M.W.; Burton, S. Analysis of role conflict and role ambiguity in a structural equations framework. J. Appl. Psychol. 1990, 75, 148. [CrossRef]

78. Harman, H.H. Modern Factor Analysis; University of Chicago Press: Chicago, IL, USA, 1976.

79. Podsakoff, P.M.; Organ, D.W. Self-reports in organizational research: Problems and prospects. J.Manag. 1986, 12, 531-544. [CrossRef]

80. Ahani, A.; Rahim, N.Z.A.; Nilashi, M. Forecasting social CRM adoption in SMEs: A combined SEM-neural network method. Comput. Hum. Behav. 2017, 75, 560-578. [CrossRef]

81. Chong, Y.L. A two-staged SEM-neural network approach for understanding and predicting the determinants of m-commerce adoption. Expert Syst. Appl. 2013, 40, 1240-1247. [CrossRef]

82. Leong, L.Y.; Hew, T.S.; Tan, W.H.; Ooi, K.B. Predicting the determinants of the NFC-enabled mobile credit card acceptance: A neural networks approach. Expert Syst. Appl. 2013, 40, 5604-5620. [CrossRef]

83. Chong, Y.L. Predicting m-commerce adoption determinants: A neural network approach. Expert Syst. Appl. 2013, 40, 523-530. [CrossRef]

84. Tan, W.H.; Ooi, K.B.; Leong, L.Y.; Lin, B. Predicting the drivers of behavioral intention to use mobile learning: A hybrid SEM-Neural Networks approach. Comput. Hum. Behavior 2014, 36, 198-213. [CrossRef]

85. Peinkofer, S.T.; Esper, T.L.; Smith, R.J.; Williams, B.D. Assessing the Impact of Price Promotions on Consumer Response to Online Stockouts. J. Bus. Logist. 2015, 36, 260-272. [CrossRef] 
86. Alexander, V.; Tripp, S.; Zak, P.J. Preliminary evidence for the neurophysiologic effects of online coupons: changes in oxytocin, stress, and mood. Psychol. Mark. 2015, 32, 977-986. [CrossRef]

87. Truong, Y.; Klink, R.R.; Fort-Rioche, L.; Athaide, G.A. Consumer response to product form in technology-based industries. J. Prod. Innov. Manag. 2014, 31, 867-876. [CrossRef]

88. Mollick, E.; Nanda, R. Wisdom or madness? Comparing crowds with expert evaluation in funding the arts. Manage. Sci. 2016, 62, 1533-1553. [CrossRef]

89. Lee, M.K.O.; Turban, E. A trust model for consumer internet shopping. Int. J. Electron. Commer. 2001, 6, 75-91. [CrossRef]

90. Chu, W.; Choi, B.; Song, M.R. The role of on-line retailer brand and infomediary reputation in increasing consumer purchase intention. Int. J. Electron. Commer. 2005, 9, 115-127. [CrossRef]

91. Hörisch, J. Crowdfunding for environmental ventures: An empirical analysis of the influence of environmental orientation on the success of crowdfunding initiatives. J. Clean. Prod. 2015, 107, 636-645. [CrossRef]

92. Lam, P.T.I.; Law, A.O.K. Crowdfunding for renewable and sustainable energy projects: An exploratory case study approach. Renew. Sustain. Energy Rev. 2016, 60, 11-20. [CrossRef]

93. Jeong, S.C.; Kim, S.H.; Park, J.Y.; Choi, B. Domain-specific innovativeness and new product adoption: A case of wearable devices. Telemat. Inform. 2017, 34, 399-412. [CrossRef]

(C) 2019 by the authors. Licensee MDPI, Basel, Switzerland. This article is an open access article distributed under the terms and conditions of the Creative Commons Attribution (CC BY) license (http://creativecommons.org/licenses/by/4.0/). 